\title{
NURSES' PERCEPTIONS AND EXPECTATIONS ON THE IMPLEMENTATION OF CAREER LADDER IN PUBLIC HOSPITALS IN MAKASSAR
}

\author{
Meyke Tiku Pasang ${ }^{1}$, Kusrini S. Kadar², Rosdiana Natzir ${ }^{3}$ \\ ${ }^{1}$ Politeknik Kesehatan Kemenkes Jayapura \\ ${ }^{2}$ Program Studi Magister Ilmu Keperawatan, Universitas Hasanuddin, Makassar \\ ${ }^{3}$ Fakultas Kedokteran, Universitas Hasanuddin, Makassar \\ e-mail : meyketikupasang83@gmail.com
}

\begin{abstract}
Introduction: Nurses as professionals must provide services in accordance with the competence and authority possessed either individually or as part of a hospital team. Thus, there is a need to manage the resources of nursing such as the professional career development system for nurses. The study aimed to identify the perception and expetation of the nurses on the implementation of career ladder in two hospitals in Makassar city. Method: This research used quantitative method with the cross sectional design. There were 105 nurses from Hasanuddin University Hospital and 212 nurses from Dr. Wahidin Sudirohusodo Hospital involved as samples in this study. The samples were chosen using the disproportionate stratified random sampling technique. The data were collected through questionnaires to find out the nurse perception including some open ended question to explore the nurses expectation from this career ladder program. The data were analyzed using descriptive statistic and mann-whitney to seee the differences perception between the groups. Result: The result revealed although that mean of perception about the implementation of career ladder in two hospitals are considered good $(\mathrm{m}=3.70$ dan $\mathrm{m}=3.94)$, there was differences of nurses perception in both hospitals $(p=0.00)$. Conclusions: Meanwhile, the result of openended questions about nurses' expectation about the implementation of the career ladder emphasized that there should be a schedule for training for their professional improvement. Evaluation for further assessment for higher levels of career ladder also considered important for the nurses in both hospitals. Furthermore, the rewards or incentives for the nurses received shold be appropriate according to the career levels. In conclusion, the implementation of career ladder program in both hospitals have been considered good, however, the hospitals need to support the nurses and pay attention to factors that could influence the nurses satisfaction of the program.
\end{abstract}

Keywords: career ladder, perception, expectation.

\section{PENDAHULUAN}

Perawat sebagai salah satu tenaga kesehatan di rumah sakit memegang peranan penting dalam keberhasilan pelayanan kesehatan yang memberikan perawatan yang berkualitas bagi pasien (Potter \& Perry, 2005). Karena perawat merupakan sumber daya terbanyak di rumah sakit dan berinteraksi lebih banyak dengan pasien. Dalam memberikan pelayanan keperawatan, perawat sebagai tenaga profesional harus memberikan pelayanan sesuai dengan kompetensi dan kewenangan yang dimiliki baik secara individu maupun sebagai bagian dari suatu tim (Depkes RI, 2006).

Untuk itu rumah sakit perlu melakukan pengelolaan sumber daya keperawatan salah satunya dengan memperhatikan sistem pengembangan karir profesional perawat. Pengembangan karir awalnya dijelaskan melalui teori From Novice to Expert oleh Patricia Benner (1984) dan dikembangkan sebagai bentuk tingkatan level jenjang karir yang biasa dikenal juga dengan istilah jenjang klinik (Clinical Ladder). Kemudian teori ini dikembangkan oleh Swansburg 
(2000) dan pada perkembangannya model jenjang karir diterapkan dan dikembangkan di berbagai negara termasuk Indonesia. Dimana jenjang karir perawat di Indonesia telah disusun oleh Persatuan Perawat Nasional Indonesia (PPNI) bersama departemen kesehatan dalam bentuk pedoman jenjang karir perawat tahun 2006 (Suroso, 2011).

Menurut beberapa penelitian, pengembangan sistem jenjang karir perawat mempunyai dampak positif terhadap perawat. Dimana dengan adanya pengembangan sistem jenjang karir perawat, dapat meningkatkan percaya diri perawat dalam memberikan pelayanan keperawatan yang berkualitas, meningkatkan pengembangan professional perawat dan memberikan reward untuk kinerja perawat yang berkualitas, sehingga meningkatkan kepuasan kerja perawat (Korman \& Eliades, 2010; Nelson \& Cook, 2008). Selanjutnya Park dan Yi (2011) melaporkan bahwa perawat Korea yang berpartisipasi dalam sistem jenjang karir mendapatkan kepuasan kerja dan rasa prestasi dalam pekerjaan mereka. Adanya kompensasi pada insentif (imbalan) juga akan meningkatkan kepuasan kerja dan kinerja klinis menjadi lebih baik (Nelson \& Cook, 2008; Han \& Kim, 2014). Dengan mengalami kemajuan klinis di sistem jenjang karir juga menjadi faktor penting dalam meningkatkan kepuasan kerja perawat (Cleary, Horsfall, Muthulakshmi, Happell \& Hunt, 2013).

Beberapa penelitian di Indonesia juga memperkuat hasil yang serupa, dimana sistem jenjang karir klinik dapat dijadikan sebagai tantangan bagi perawat untuk terus berkembang dalam pekerjaannya, sehingga dapat menjadi alat yang digunakan sebagai panduan dalam menentukan kebijakan promosi yang akan meningkatkan kepuasan kerja perawat (Suroso, 2011). Pendapat tersebut sejalan dengan hasil penelitian yang telah dilakukan oleh Chanafi (2005), Sitinjak (2008),
Saragih (2013) dan Reza (2015) yang menyatakan bahwa ada hubungan sistem jenjang karir dengan kepuasan kerja perawat. Tidak dilaksanakannya jenjang karir perawat di rumah sakit akan memberikan dampak pada tingkat kepuasan perawat di rumah sakit dan akan mempengaruhi motivasi kerja perawat. Perawat merasa bahwa kinerja mereka tidak dihargai dan hal ini cenderung membuat perawat meninggalkan rumah sakit (turnover). (Kurniadi, 2013; Ratanto, Mustikasari \& Kuntarti, 2014).

Hasil survey yang dilakukan oleh bidang SDM RS Universitas Hasanuddin, didapatkan bahwa sistem jenjang karir dapat berdampak pada penurunan jumlah turn over dan kepuasan kerja perawat. Jumlah turn over perawat tahun 2015 sebanyak 13 orang dan menurun menjadi 3 orang tahun 2016 (Bidang SDM, 2016a). Penilaian kepuasan kerja terhadap pengembangan karir perawat menunjukkan kepuasan kerja perawat dengan persentase sekitar $52.8 \%$ pada perawat di 12 ruangan yaitu Rawat Inap VVIP, VIP, Kelas I, Kelas 2/3, Rawat Inap Mata, Poliklinik, Kemoterapi, Neonatal Intensive Care Unit (NICU), Intensive Care Unit (ICU), Hemodialisa, Instalasi Rawat Darurat (IRD) dan Centra Operation Theatre (COT) (Bidang SDM, 2015).

Walaupun pelaksanaan jenjang karir sudah berjalan di kedua rumah sakit tersebut, tetapi belum ada evaluasi mengenai persepsi perawat dan harapannya terhadap pelaksanaan jenjang karir ini. Oleh sebab itu penelitian ini dapat memberikan data tentang evaluasi pelaksanaan sistem pengembangan jenjang karir perawat yang dapat menjadi acuan pengembangan oleh sarana kesehatan yang lain.

\section{METODE}

Penelitian ini merupakan penelitian kuantitatif dengan pendekatan cross sectional dalam membandingkan persepsi perawat di 
dua rumah sakit yang melaksanakan program jenjang karir. Jumlah sampel sebanyak 105 orang di RS Universitas Hasanuddin (RSUH) dan 212 orang di RSUP Dr. Wahidin Sudirohusodo (RSWS). Sampling dipilih dengan menggunakan teknik disproportionate stratified random sampling.

Data dikumpulkan dengan kuesioner skala likert dan dianalisis secara univariat melalui distribusi frekuensi untuk mengetahui persepsi perawat tentang pelaksanaan jenjang karir dan bivariat dengan menggunakan uji mann-whitney untuk melihat perbedaan persepsi perawat tentang pelaksanaan jenjang karir di RSUH dan RSWS. Serta pertanyaan terbuka mengenai harapan perawat untuk pelaksanaan jenjang karir selanjutnya serta wawancara dengan Key Person di kedua rumah sakit untuk mengklarifikasi lebih lanjut data yang didapatkan.

\section{HASIL}

\section{Karakteristik Responden}

Tabel 1 memperlihatkan karakteristik responden pada penelitian ini. Secara umum rata-rata usia responden di RSUH berusia 28 tahun dengan lama kerja 4.4 tahun sedangkan responden di RSWS berusia 33 tahun dengan lama kerja sekitar
8.6 tahun. Mayoritas responden pada kedua lokasi penelitian adalah perempuan $(85.7 \%$ di RSUH dan $87.1 \%$ di RSWS).

Tingkat pendidikan responden di RSUH mayoritas memiliki tingkat pendidikan Ners (77.1\%), sedangkan di RSWS jumlah responden yang memiliki pendidikan D3 lebih banyak dibanding ners walaupun perbedaan jumlahnya tidak banyak (50.6\% dan 48.9\% secara berurutan). Di RSUH, jumlah responden yang sudah menikah dan belum menikah tidak terlalu jauh berbeda (51.4\% dan 48.6\%) tetapi kondisi berbeda ditemukan di RSWS di mana lebih dari setengah jumlah responden memiliki status sudah menikah (67.7\%). Responden di RSWS mayoritas bekerja di bangsal umum $(81.7 \%)$ sementara di RSUH jumlah responden yang bekerja di bangsal umum dan khusus hampir sama (47,6\% dan 52.4\%). Untuk level jenjang karir, kedua RS memulai di level pra $\mathrm{PK}$, tetapi di RSUH hanya sampai level PK 2 dengan jumlah lebih dari setengah jumlah responden di RSUH memiliki tingkat jenjang karir PK 1 (57.1\%). Kondisi level jenjang karir di RSWS berbeda, walaupun jumlah terbesar juga ada di level PK 1 (46.2\%) tetapi penyebaran jumlah perawat di level PK 2 dan 3 memperlihatkan angka yang cukup signifikan. 


\begin{tabular}{lcccccc}
\hline \multirow{2}{*}{ Variabel } & \multicolumn{2}{c}{ RSUH } & \multicolumn{2}{c}{ RSWS } & \multicolumn{2}{c}{ TOTAL } \\
\cline { 2 - 7 } & $\mathbf{n}$ & $\%$ & $\mathbf{n}$ & $\%$ & $\mathbf{N}$ & $\%$ \\
\hline Jenis kelamin & & & & & & \\
Laki - laki & 15 & 14.3 & 24 & 12.9 & 39 & 13.4 \\
Perempuan & 90 & 85.7 & 162 & 87.1 & 252 & 86.6 \\
Tingkat Pendidikan & & & & & & \\
D3 & 19 & 18.1 & 94 & 50.6 & 113 & 38.8 \\
Ners & 81 & 77.1 & 91 & 48.9 & 172 & 59.1 \\
S2 Kep & 5 & 4.8 & 1 & 0.5 & 6 & 2.1 \\
Lainnya & 0 & 0 & 0 & 0 & 0 & 0 \\
Status & & & & & & \\
Belum Menikah & 51 & 48.6 & 60 & 32.3 & 111 & 38.1 \\
Menikah & 54 & 51.4 & 126 & 67.7 & 180 & 61.9 \\
Unit Kerja & & & & & & \\
Bangsal Umum & 50 & 47.6 & 152 & 81.7 & 202 & 69.4 \\
Bangsal Khusus & 55 & 52.4 & 34 & 18.3 & 89 & 30.6 \\
Level Jenjang Karir & & & & & & \\
Pra PK & 8 & 7.6 & 8 & 4.3 & 16 & 5.5 \\
PK 1 & 60 & 57.1 & 86 & 46.2 & 146 & 50.2 \\
PK 2 & 37 & 35.2 & 51 & 27.4 & 88 & 30.2 \\
PK 3 & 0 & 0 & 41 & 22.1 & 41 & 14.1 \\
\hline Tabel 1. Distribusi Responden berdasarkan Jenis Kelamin Unit keria dan status, dam
\end{tabular}

unit kerja di RS Universitas Hasanuddin $(n=105)$ dan di RSUP Dr.Wahidin Sudirohusodo $(\mathrm{n}=212)$

\begin{tabular}{lcccc}
\hline \multirow{2}{*}{ Variabel } & \multicolumn{2}{c}{ RSUH } & \multicolumn{2}{c}{ RSWS } \\
\cline { 2 - 5 } & Mean (SD) & Min - Max & Mean (SD) & Min - Max \\
\hline Umur & $28.6(2.1)$ & $23-40$ & $33.15(7.8)$ & $23-56$ \\
Lama kerja & $4.4(1.25)$ & $2-7$ & $8.66(7.65$ & $1-35$ \\
\hline
\end{tabular}

Tabel 2. Distribusi responden berdasarkan usia dan lama kerja di RS Universitas Hasanuddin $(n=105)$ dan RSUP Dr. Wahidin Sudirohusodo $(n=212)$

\section{Persepsi perawat tentang pelaksanaan jenjang karir di RSUH dan RSWS}

Secara umum hasil penelitian ini memperlihatkan persepsi perawat mengenai pelaksanaan jenjang karir di kedua rumah sakit dalam rentang baik. Tabel 2 memperlihatkan nilai mean dari persepsi perawat di kedua rumah sakit tidak begitu jauh yaitu $(\mathrm{m}=3.70$ dan $\mathrm{m}=3.94$ di $\mathrm{RSUH}$ dan RSWS). Ini memperlihatkan bahwa persespi perawat di kedua rumah sakit mengenai pelaksanaan jenjang karir sudah baik karena rata-rata mereka sudah memperlihatkan pendapat setuju terhadap pelaksanaan jenjang karir. Jika dilihat dari mean setiap pertanyaan dari responden di kedua rumah sakit, secara umum memiliki nilai mean yang sama kecuali pada pertanyaan mengenai insentif dan penghargaan terdapat perbedaan nilai mean, di mana responden di RSUH memperlihatkan respon $\mathrm{ne}(\mathrm{m}=3.01)$ dibandingkan dengan responden di RSWS $(\mathrm{m}=3.84)$ yang menunjukkan respon setuju terhadap poin insentif dan penghargaan yang mereka terima dari pelaksanaan jenjang karir ini.

Peneliti juga melakukan uji perbedaan untuk melihat perbedaan respon dari responden di kedua rumah sakit. Tabel 3 memperlihatkan hasil uji Mann-Whitney bahwa ada perbedaan persepsi perawat tentang pelaksaan 


\begin{tabular}{|c|c|c|c|c|c|}
\hline \multirow{2}{*}{ No } & \multirow{2}{*}{ Pertanyaan } & \multicolumn{2}{|c|}{ RS-UH } & \multicolumn{2}{|c|}{ RSWS } \\
\hline & & $\mathbf{M}$ & SD & $\mathbf{M}$ & SD \\
\hline 1. & $\begin{array}{l}\text { Jenjang karir merupakan cara yang efektif untuk } \\
\text { mengenali bakat/keahlian saya dalam keperawatan }\end{array}$ & 4.18 & 0.45 & 4.18 & 0.59 \\
\hline 2. & $\begin{array}{l}\text { Saya mendapat kesempatan untuk memperoleh } \\
\text { pengetahuan, keterampilan, dan aktivitas dalam } \\
\text { memenuhi level jenjang karir saya }\end{array}$ & 3.91 & 0.52 & 4.12 & 0.62 \\
\hline 3. & $\begin{array}{l}\text { Jenjang karir memungkinkan saya untuk memilih } \\
\text { tingkat keterlibatan yang saya inginkan dalam } \\
\text { kegiatan keperawatan }\end{array}$ & 3.85 & 0.58 & 4.03 & 0.64 \\
\hline 4. & $\begin{array}{l}\text { Saya percaya bahwa lingkungan yang diciptakan oleh } \\
\text { level jenjang karir mendorong saya untuk menerima } \\
\text { tanggung jawab dan akuntabilitas untuk praktik } \\
\text { klinis saya }\end{array}$ & 3.82 & 0.63 & 3.97 & 0.65 \\
\hline 5. & $\begin{array}{l}\text { Standar untuk setiap tingkat level jenjang karir secara } \\
\text { akurat mencerminkan praktik pada tingkat itu. }\end{array}$ & 3.78 & 0.60 & 3.91 & 0.73 \\
\hline 6. & $\begin{array}{l}\text { Setiap tingkat level jenjang karir menggambarkan } \\
\text { peran yang berbeda dalam praktik keperawatan. }\end{array}$ & 3.82 & 0.58 & 3.87 & 0.75 \\
\hline 7. & $\begin{array}{l}\text { Memberikan contoh pelaksanaan praktik keperawatan } \\
\text { melalui penulisan kejadian kritis untuk Portofolio } \\
\text { level jenjang karir, meningkatkan kesadaran saya } \\
\text { akan pentingnya mendeskripsikan praktik profesional } \\
\text { saya. }\end{array}$ & 3.76 & 0.55 & 3.95 & 0.67 \\
\hline 8. & $\begin{array}{l}\text { Level jenjang karir secara efektif mendorong saya } \\
\text { untuk terlibat dalam kegiatan yang secara langsung } \\
\text { mempengaruhi perawatan pasien. }\end{array}$ & 3.89 & 0.47 & 3.98 & 0.66 \\
\hline 9. & $\begin{array}{l}\text { Harapan dari setiap level jenjang karir ditinjau ulang } \\
\text { / diassessment ulang terhadap saya sehingga saya } \\
\text { mengerti dengan jelas apa yang diharapkan dari diri } \\
\text { saya. }\end{array}$ & 3.77 & 0.64 & 3.99 & 0.69 \\
\hline 10. & $\begin{array}{l}\text { Harapan kerja untuk level saya di tingkat jenjang } \\
\text { karir dengan jelas dan akurat menggambarkan } \\
\text { pekerjaan yang saya lakukan. }\end{array}$ & 3.73 & 0.61 & 3.91 & 0.67 \\
\hline 11. & $\begin{array}{l}\text { Proses penilaian dari rekan saya di level jenjang } \\
\text { karir adalah cara yang efektif untuk mengevaluasi } \\
\text { seberapa baik standar kinerja saya. }\end{array}$ & 3.70 & 0.73 & 3.89 & 0.71 \\
\hline 12. & $\begin{array}{l}\text { Evaluasi portofolio saya menggunakan Standar } \\
\text { kinerja jenjang karir cukup adil dan merata. }\end{array}$ & 3.44 & 0.77 & 3.89 & 0.72 \\
\hline 13. & $\begin{array}{l}\text { Saya tahu persis apa yang harus saya lakukan untuk } \\
\text { maju di level jenjang karir selanjutnya. }\end{array}$ & 3.62 & 0.67 & 3.90 & 0.68 \\
\hline 14. & $\begin{array}{l}\text { Saat saya maju di level jenjang karir selanjutnya, saya } \\
\text { diharapkan untuk memberikan perawatan kepada } \\
\text { klien dengan kompleksitas dan intensitas kebutuhan } \\
\text { yang lebih besar. }\end{array}$ & 3.87 & 0.56 & 4.11 & 0.60 \\
\hline 15. & $\begin{array}{l}\text { Saya didorong untuk bekerja dan mengalami } \\
\text { kemajuan di level jenjang karir. }\end{array}$ & 3.69 & 0.70 & 4.10 & 0.59 \\
\hline
\end{tabular}

Tabel 2. Rata-rata Persepsi Perawat terhadap Pelaksanaan Jenjang Karir (Mean) 


\begin{tabular}{|c|c|c|c|c|c|}
\hline \multirow{2}{*}{ No } & \multirow{2}{*}{ Pertanyaan } & \multicolumn{2}{|c|}{ RS-UH } & \multicolumn{2}{|c|}{ RSWS } \\
\hline & & $\mathbf{M}$ & SD & $\mathbf{M}$ & SD \\
\hline 16. & $\begin{array}{l}\text { Saya percaya bahwa kemajuan di level jenjang karir } \\
\text { dihargai oleh rekan perawat saya. }\end{array}$ & 3.64 & 0.67 & 4.04 & 0.66 \\
\hline 17. & $\begin{array}{l}\text { Jenjang karir memberikan kesempatan promosi yang } \\
\text { sesuai saat saya berada dalam praktik klinis. }\end{array}$ & 3.48 & 0.86 & 3.90 & 0.72 \\
\hline 18. & $\begin{array}{l}\text { Saya percaya penghargaan dan insentif untuk maju } \\
\text { di level jenjang karir itu adil dan merata. }\end{array}$ & 3.01 & 1.02 & 3.83 & 0.76 \\
\hline 19. & $\begin{array}{l}\text { Kemajuan di level jenjang karir memberikan rasa } \\
\text { prestasi dan kepuasan professional dalam karir } \\
\text { keperawatan saya }\end{array}$ & 3.56 & 0.75 & 4.02 & 0.65 \\
\hline 20. & $\begin{array}{l}\text { Saya tidak akan mempertimbangkan pekerjaan dalam } \\
\text { situasi yang tidak memiliki program pengembangan } \\
\text { karir seperti level jenjang karir. }\end{array}$ & 3.27 & 0.82 & 3.43 & 0.91 \\
\hline 21. & $\begin{array}{l}\text { Kemajuan di level jenjang karir mendorong saya } \\
\text { untuk menggunakan inisiatif dan penilaian pribadi } \\
\text { saya dalam memberikan asuhan keperawatan. }\end{array}$ & 3.70 & 0.60 & 3.95 & 0.66 \\
\hline 22. & $\begin{array}{l}\text { Kemajuan di level jenjang karir mendorong saya } \\
\text { untuk menjadi panutan dengan menerapkan konsep } \\
\text { praktik klinis lanjutan untuk meningkatkan kualitas } \\
\text { asuhan keperawatan yang saya berikan. }\end{array}$ & 3.87 & 0.52 & 4.03 & 0.63 \\
\hline SKO & RATA-RATA & 3.70 & 0.42 & 3.94 & 0.43 \\
\hline
\end{tabular}

Tabel 2. Lanjutan... Rata-rata Persepsi Perawat terhadap Pelaksanaan Jenjang Karir (Mean)

\begin{tabular}{cccccc}
\hline Variabel & $\begin{array}{c}\text { Median } \\
\text { (Min-Max) }\end{array}$ & U & P & Z & R \\
\hline Persepsi RSUH (n=105) & $3.77(2-5)$ & 7349.5 & 0.000 & -4.93 & 0.02 \\
\hline Persepsi RSWS (n=212) & $3.95(2-5)$ & & & &
\end{tabular}

Tabel 3. Perbedaan persepsi perawat RSUH dan RSWS

\begin{tabular}{clcccc}
\hline VARIABEL & \multicolumn{1}{c}{ ITEM } & RS-UH & RSWS & TOTAL & $\%$ \\
\hline $\begin{array}{c}\text { Pertumbuhan } \\
\text { perofesional }\end{array}$ & Jadwal Pelatihan & 93 & 184 & 277 & 87 \\
\cline { 2 - 6 } Motivasi & 47 & 40 & 87 & 27 \\
\hline Prestasi Kerja & $\begin{array}{l}\text { A s s e s m e n t } \\
\text { Lanjutan }\end{array}$ & 65 & 144 & 209 & 66 \\
\hline $\begin{array}{c}\text { Reward / } \\
\text { Remunerasi }\end{array}$ & Evaluasi Kinerja & 65 & 77 & 142 & 45 \\
\cline { 2 - 6 } & Insentif sesuai level & 90 & 162 & 252 & 79 \\
\hline
\end{tabular}

Tabel 4. Harapan Perawat terhadap Pelaksanaan Jenjang Karir

\section{Harapan Perawat terhadap pelaksanaan jenjang karir di RSUH dan RSWS}

Hasil dari pertanyaan terbuka tentang harapan perawat tentang pelaksanaan jenjang karir menekankan

bahwa harus ada jadwal pelatihan untuk peningkatan profesional mereka (RSUH=93, RSWS=184). Evaluasi untuk penilaian lebih lanjut untuk jenjang karir yang lebih tinggi juga dianggap penting bagi perawat di kedua rumah sakit (RSUH=65-65, RSWS=209142) bahwa untuk pertumbuhan professional.

Selanjutnya, penghargaan atau insentif bagi perawat yang diterima seharusnya sesuai dengan tingkat karir (RSUH=90, RSWS=162)( lihat tabel 4).

\section{PEMBAHASAN}

Di Indonesia pelaksanaan jenjang karir di RS sudah dimulai sejak tahun 2006. Terdapat perbedaan penerapan 
program jenjang karir di Indonesia dengan negara lain misalnya Jepang, di mana di negara maju seperti Jepang, jenjang karir merupakan pilihan dari perawat. Di Indonesia, jenjang karir ini berlaku untuk semua perawat tanpa terkecuali (baik pegawai tetap maupun tidak) dan tidak ada pilihan lain. Walaupun demikian, secara umum penelitian ini memperlihatkan hasil bahwa perawat yang ada di RS lokasi penelitian sepertinya sudah merasakan manfaat dari pelaksanaan jenjang karir ini, hal ini dapat terlihat bahwa rata-rata responden di kedua lokasi penelitian setuju terhadap pelaksanaan jenjang karir. Akan tetapi terdapat beberapa perbedaan persepsi antara kedua RS mengenai detail pelaksanaan jenjang karir. Hal yang paling berbeda adalah persepsi mengenai insentif akan reward yang mereka terima sesuai dengan level PK mereka. Perawat di RS Unhas lebih merasa pesimis dengan kondisi ini dibandingkan rekan mereka di RSWS. Hal ini mungkin disebabkan karena sistem reward di RSWS lebih baik daripada di RS Unhas.

Berdasarkan hasil wawancara lebih lanjut, perawat RSWS memberikan gambaran mengenai insentif yang mereka dapatkan yang nilainya lebih dari jumlah yang diterima oleh perawat RS Unhas. Hal ini tentu berdampak kepada respon mereka terhadap pertanyaan ini. Organisasi dalam hal ini pihak manajemen seharusnya lebih bisa memberikan perhatian yang lebih karena hal ini bisa berdampak terhadap kinerja mereka. Walaupuin pelaksanaan jenjang karir sebagai sumber daya yang kuat yang mengarah ke pertumbuhan profesional sehingga dapat dimanfaatkan sebagai program untuk mempromosikan karir secara klinis dan akhirnya bisa memotivasi pelayanan keperawatan berkualitas tinggi (Park\&Yi, 2011), hal ini tidak bisa terjadi jika perawat tidak merasa dihargai salah satunya dengan pemberian reward atau insentif yang dirasa adil oleh perawat tersebut. Temuan ini juga sejalan dengan hasil penelitian Park dan Lee (2010) yang menunjukkan bahwa perawat yang mengikuti sistem jenjang karir menganggap itu memungkinkan pertumbuhan profesional mereka.

Sementara itu, hasil dari pertanyaan terbuka tentang harapan perawat tentang pelaksanaan jenjang karir menekankan bahwa harus ada jadwal pelatihan untuk peningkatan profesional mereka. Dukungan organisasi juga sangat diperlukan dalam memberikan pesan positif kepada perawat dalam pelatihan staf sebagai bentuk pengembangan profesional. Ini akan membantu perawat mempertahankan praktik keperawatan terbaik dan memfasilitasi pengembangan dan kemajuan karir perawat (McCabe \& Garavan, 2008). Evaluasi untuk penilaian lebih lanjut untuk jenjang karir yang lebih tinggi juga dianggap penting bagi perawat di kedua rumah sakit. Menyediakan perawat dengan kesempatan untuk kemajuan klinis mungkin menjadi faktor penting dalam meningkatkan kepuasan kerja perawat klinis (Corley, Farley, Gedded, Goodloe \& Green, 1994). Selanjutnya, penghargaan atau insentif bagi perawat yang diterima seharusnya sesuai dengan tingkat karir. Kenaikan insentif dan pemberian reward pada program jenjang karir dapat meningkatkan kepuasan perawat (Drenkard \& Swartwout, 2005)

\section{KESIMPULAN}

Penerapan program jenjang karir di kedua rumah sakit telah dianggap baik, namun rumah sakit perlu mendukung perawat dan memperhatikan faktor-faktor yang dapat mempengaruhi kepuasan perawat terhadap program. Dari semua harapan perawat, manajemen keperawatan harus mengidentifikasi berbagai kebutuhan perawat dalam pengembangan sistem jenjang karir ke depannya.

\section{DAFTAR PUSTAKA}

Alligood., Martha, R., and Marriner, A. (2014). 
Nursing theorists and their work 8th ed. St.Louis : Mosby Inc, USA.

Badan Pengembangan dan Pemberdayaan SDM Kesehatan, Kementerian Kesehatan Republik Indonesia. (2012). Joint Coordinating Committee (JCC) ke 4 project enhancement of nursing competencies through in service training. http://www. bppsdmk.depkes.go.id/web/index.php ?select $=$ berita\&bid $=2237 \&$ judul $=$ pembe ntukan\%20unit $\% 20$ pengembangan $\% 20$ pendidikan $\% 20$ profesional $\% 20$ kesehatan\%20.

Bidang Sumber Daya Manusia. (2015). Tingkat kepuasan kerja perawat $R S$ Universitas Hasanuddin.

Bidang Sumber Daya Manusia. (2016a). Jumlah turnover perawat RS Universitas Hasanuddin.

Cleary, M., Horsfall, J., Muthulakshmi, P., Happell, B., and Hunt, G.E. (2013). Career development: graduate nurse views. Journal of Clinical Nursing. 22 : 2605-2613.

Corley, M., Farley, B., Gedded, M., Goodloe, L., and Green, P. (1994). The clinical ladder: impact on nurse satisfaction and turnover. Journal of Nurse Administration, 24(2), 42-48.

Departemen Kesehatan. (2006). Pedoman pengembangan jenjang karir profesional perawat. Direktorat Bina Pelayanan Keperawatan Direktorat Jenderal Bina Pelayanan Medik Departemen Kesehatan RI. Jakarta.

Drenkard, K., \& Swartwout, E. (2005). Effectiveness of a clinical ladder program. Journal of Nursing Administration,35(11), 502-506.

Han YoungHee; Kim KyungSook. (2014). The recognition and expecting need of nurses' the career ladder system in the small to medium sized hospitals. International Information Institute (Tokyo). Volume 17, No.12(A) : 6297-6306.

Korman C., and Eliades A. B. (2010). Evaluation through research of a three-track career ladder program for registered nurses. Journal of Nurses Staff Development. 26(6), 260-266.

Marquis, B.L., \& Huston, C. J. (2010). Kepemimpinan dan manajemen keperawatan: teori \& aplikasi, ed 4, alih Bahasa, Widyawati dkk, Editor edisi bahasa Indonesia Egi komara yuda dkk. Jakarta: EGC.

McCabe, T.J., \& Garavan, T.N. (2008). A study of the drivers of commitment amongst nurses: The salience of training, development and career issues. Journal of European Industrial Training, 32(7), 528-568. Retrieved from Doi:10.1108/03090590810899829.

Nelson, Joan. M., and Cook, Paul. F. (2008). Evaluation of a career ladder program in an ambulatory care environment. Nursing Economics, The Journal for Health Care Leaders. Volume 26 : 353-360.

Notoatmodjo S. (2012). Metodologi Penelitian Kesehatan. Jakarta: Rineka Cipta.

Park Kwang-Ok; Yi Myungsun. (2011). Nurses' experience of career ladder programs in a general hospital. Journal of Korean Academy of Nursing. Vol. 41 Issue 5, 581-592.

Potter P.A. \& Perry A. G. (2005). Fundamental of nursing: concepts, process and practice. Harcourt Australia: Mosby.

Ratanto., Mustikasari., dan Kuntarti. (2013). Pengembangan karir sebagai faktor paling mempengaruhi kinerja perawat pelaksana. Jurnal Keperawatan Indonesia, Vol. 16, No. 2.

Reza R. S. (2015). Hubungan persepsi tentang jenjang karir dengan motivasi kerja dan kepuasan kerja perawat di Rumah Sakit Umum Daerah Tugurejo Semarang. Masters thesis, Diponegoro University.

Rivai F. (2013). Analisis faktor dominan yang mempengaruhi kinerja pegawai dalam melaksanakan asuhan keperawatan Di Ruang Rawat Inap RSUD Haji Surabaya. Tesis Universitas Airlangga Surabaya.

Saryono dan Anggraeni. (2010). Metodologi penelitian kualitatif dalam bidang kesehatan.Yogyakarta : Nuha Medika.

Saragih, S.G. (2013). Hubungan jenjang karir dengan kepuasan kerja perawat di Rumah Sakit Santo Borromeus. E-Journal STIKES Santo Borromeus, Bandung.

Sitinjak L. (2008). Pengaruh penerapan sistem jenjang karir terhadap kepuasan perawat di RS PGI "Cikini" Jakarta. Depok: FIK UI.

Sugiyono. (2016). Metode penelitian kuantitatif, kualitatif dan $R$ dan $D$. Bandung : Alfabeta.

Suroso J. (2011). Penataan sistem jenjang karir berdasarkan kompetensi untuk meningkatkan kepuasan kerja dan kinerja perawat di Rumah Sakit. Explanasi, volume 6, no. 2 .

Swansburg R.C. (2000). Kepemimpinan dan manajemen keperawatan. untuk perawat klinis. Alih Bahasa Suharyati Samba. Jakarta: EGC 